\title{
Chemical Inhibition of the Contaminant Lactobacillus fermentum from Distilleries Producing Fuel Bioethanol
}

\author{
Pedro de Oliva Neto ${ }^{1 *}$, Fabíola Aliaga de Lima ${ }^{1}$, Ketrin Cristina da Silva ${ }^{1}$, Douglas \\ Fernandes da Silva ${ }^{1}$, Ana Flavia Azevedo Carvalho ${ }^{2}$ and Catarina dos Santos ${ }^{1}$ \\ ${ }^{I}$ Departamento de Ciências Biológicas; Laboratório de Biotecnologia Industrial; Universidade Estadual Paulista; \\ Assis - SP - Brasil. ${ }^{2}$ Faculdade de Engenharia de Alimentos; Universidade Estadual de Campinas; Campina - SP - \\ Brasil
}

\begin{abstract}
The purpose of this study was to determine the Minimum Inhibitory Concentration (MIC) of pure or mixed chemicals for Saccharomyces cerevisiae and Lactobacillus fermentum in the samples isolated from distilleries with serious bacterial contamination problems. The biocides, which showed the best results were: 3,4,4' trichlorocarbanilide (TCC), tested at pH 4.0 (MIC = $3.12 \mathrm{mg} / \mathrm{l})$, TCC with benzethonium chloride $(\mathrm{CBe})$ at $\mathrm{pH} 6.0$ $(M I C=3.12 \mathrm{mg} / \mathrm{l})$ and TCC mixed with benzalkonium chloride $(\mathrm{CBa})$ at $\mathrm{pH} 6.0(\mathrm{MIC}=1.53 \mathrm{mg} / \mathrm{l})$. If CBa was used in sugar cane milling in 1:1 ratio with TCC, a 8 times reduction of CBa was possible. This formulation also should be tested in fermentation steps since it was more difficult for the bacterium to develop resistance to biocide. There was no inhibition of S. cerevisiae and there were only antibiotics as an option to bacterial control of fuel ethanol fermentation by S. cerevisiae.
\end{abstract}

Key words: Ethanol, lactic acid bacteria, Saccharomyces cerevisiae, Lactobacillus fermentum

\section{INTRODUCTION}

Currently, bioethanol is considered an important recycled fuel and an alternative to fossil fuels. In Brazil, it is produced by fed-batch or continuous fermentation process from sugar cane using Saccharomyces cerevisiae in cell recycles. In this process, the microbial contaminants are also recycled. Bacterial contamination is an aggravating factor associated with several problems such as the consumption of sugar, alcohol and other medium components, reduction in ethanol yield (Oliva-Neto and Yokoya 1994, 1996); release of toxins and organic acids in the work, and decrease in the viability of yeast cells (Maiorella et al. 1983, Essia-Ngang et al. 1989, Dorta et al. 2007). It is well known that in the fermentation process, Gram-positive bacteria are the main agents of contamination, especially Lactobacillus spp. (Galo 1989; Oliva-Neto 1990). The antagonism between $L$. fermentum and $S$. cerevisiae is due to organic acids produced by the bacterial cells (Oliva-Neto and Yokoya 1994, 1996). Furthermore, L. fermentum is a contaminant agent responsible for yeast flocculation, which is associated with corrosion and obstruction of pumps and centrifuges and a decrease in antibiotic effectiveness and fermentation yield (Oliva-Neto and Yokoya 1991; Ludwig et al. 2001).

In the fermentation process, antibiotics are added to control bacterial contamination, but use of these compounds is limited. This method of control is limited to a few products. Currently, HJ Kamoran is widely used in Brazilian distilleries, but at a

*Author for correspondence: poliva@assis.unesp.br 
high cost. Thus, the discovery of new products with antimicrobial activity against $L$. fermentum is necessary. Inhibitory action against the growth of L. fermentum has been determined for acid penicillin V (MIC 0.10-0.20 mg/L), clindamycin (MIC 0.05-0.40 mg/L), sulphite (MIC 10-40 $\mathrm{mg} / \mathrm{L})$, thiocianate $(1.2-5.0 \mathrm{mg} / \mathrm{L})$, formaldehyde (11.5-23 mg/L), cephamandole $(0.26-1.45 \mathrm{mg} / \mathrm{L})$, bromophenate $\quad(9-18 \quad \mathrm{mg} / \mathrm{L})$, methyldithiocarbamate $(2.5 \mathrm{mg} / \mathrm{L})$, copper sulphate $(75-300 \mathrm{mg} / \mathrm{L})$ and N-alkyl dimethylbenzyl ammonium chloride or benzalkonium chloride (MIC $8.0 \mathrm{mg} / \mathrm{L}$ ) (Oliva-Neto and Yokoya 2001). Polymixin B sulphate showed MIC of 64 $\mathrm{mg} / \mathrm{L}$ against $L$. fermentum, which was more than $1024 \mathrm{mg} / \mathrm{L}$ for other species of Lactobacillus spp. (Flores et al. 2008). The MIC of gentamicin against $L$. plantarum was $128 \mathrm{mg} / \mathrm{L}$, but this antibiotic did not perform well against other species of Lactobacillus spp. (Rojo-Bezares et al. 2006). According to Danielsen and Wind (2003), metronidazole was not effective in inhibiting Lactobacillus spp. (MIC> $200 \mathrm{mg} / \mathrm{L}$ ). The surfactants sodium lauryl sulphate, benzethonium chloride and benzalkonium chloride were also evaluated for inhibiting the growth of $L$. fermentum and S. cerevisiae (Silva et al. 1997). The 3,4,4' trichlorocarbanilide demonstrated a selective inhibition against $L$. fermentum and Leuconostoc mesenteroides (Oliva-Neto and Yokoya 1998).

In this work, in vitro antimicrobial activity (MIC) against $L$. fermentum and $S$. cerevisiae was determined for several antimicrobial compounds aiming to find new alternatives for the control of bacterial contamination in fuel ethanol production.

\section{MATERIALS AND METHODS}

\section{Microorganisms}

The bacterial cultures used in this study were $L$. fermentum CCT 1396, isolated from an alcohol distillery by Oliva-Neto and Yokoya (1994), and L. fermentum CCT 0559, obtained from the Tropical Culture Collection (CCT), Campinas Brazil. Both the strains were activated and maintained in Man Rogosa, Sharpe medium (Difco) at $\mathrm{pH} 4.5$. The yeast strains used were $S$. cerevisiae CCT 4370, obtained from the Tropical Culture Collection, and S. cerevisiae FCLA M26, also isolated from an alcohol distillery (Oliva-Neto et al. 2004) and obtained from the Culture
Collection of the Laboratory of Industrial Biotechnology, São Paulo State University (UNESP), Assis - Brazil. Yeast strains were activated and maintained in nutrient medium consisting of $(\%, w / v) 2$ sucrose, 0.5 yeast extract, $\begin{array}{lllll}0.1 & \left(\mathrm{NH}_{4}\right)_{2} \mathrm{SO}_{4}, & 0.114 & \mathrm{~K}_{2} \mathrm{HPO}_{4} \cdot 3 \mathrm{H}_{2} \mathrm{O}, & 0.0017\end{array}$ $\begin{array}{llll}\mathrm{MnSO}_{4} .7 \mathrm{H}_{2} \mathrm{O}, & 0.0028 & \mathrm{ZnSO}_{4} .7 \mathrm{H}_{2} \mathrm{O}, & 0.024\end{array}$ $\mathrm{MgSO}_{4} .7 \mathrm{H}_{2} \mathrm{O}$ and distilled water. All the cultures were incubated at $30^{\circ} \mathrm{C}$ for $24-48 \mathrm{~h}$.

\section{Minimum inhibitory concentration (MIC)}

The following chemicals were tested for MIC at 1$40 \mathrm{mg} / \mathrm{l}$ : nalidixic acid (Sanofi-Synthelabo Ltda.), pipemidic acid (Zambon Pharmaceutical Laboratories Ltda), phenazopyridine hydrochloride (Blanver Farmoquímica Ltda.), metronidazole (Aventis Pharma Ltda.), nitrofurantoin (Laboratory Teuto Brasileiro S/A), sulphasalazine (Apsen Farmacêutica S/A), sulphamethoxazole/ trimethoprim (Roche Chemicals and Pharmaceutical Products S.A), sulphadiazine silver (Pharma Nostra), gentamicin sulphate (Lab Duct Pharmaceutical Industry Ltda), sulfacetamide sodium (Henrifarma) and polymyxin B sulphate (American Farmasa Laboratory of pharmacotherapy SA). Pipemidic acid and nitrofurantoin were formulated with sodium dodecyl sulfate (SDS) (3:1 and 1:1, w/w) to evaluate the synergistic effect with this compound. The other tested chemicals were at $250-4000 \mathrm{mg} / \mathrm{L}$ tartaric acid and sodium gluconate, and at $0.78-12.5 \mathrm{mg} / \mathrm{L} \quad 3,4,4$ ' trichlorocarbanilide (TCC), benzethonium chloride (Cbe), benzalkonium chloride (Cba), cetyl trimethyl ammonium chloride (CTA) and $\mathrm{Hj}$ Kamoran $^{\circledR}$ (the antibiotic Monensin - Química Real - Ribeirão Preto - SP - Brazil). The products Cbe, Cba, tartaric and gluconate acids were dissolved in distilled water. TCC was dissolved in acetone. All the chemicals were autoclaved $\left(121^{\circ} \mathrm{C} / 15 \mathrm{~min}\right)$ or microfiltered $(0.22 \mu \mathrm{m}$ membrane Millipore - EUA).

The MIC of these chemicals was determined by adapted macrodilution broth method (Jones et al. 1985). Assays were performed in the tubes containing $6.0 \mathrm{~mL}$ medium. The inoculum was standardized according to MacFarland 0.5 standard in aseptic conditions. The cultures were incubated at $30^{\circ} \mathrm{C}$ for $24 \mathrm{~h}$ in an incubator and bacterial growth was aseptically measured by absorbance at $600 \mathrm{~nm}$ wavelength $\left(\mathrm{A}_{600}\right)$ by using a spectrophotometer (Spectronic 1100 Pharmacia USA). The MIC was defined as the minimum 
concentration able to inhibit at least $90 \%$ the microbial growth and performed in triplicate. The growth reduction was calculated as $\left[1-\left[\left(\mathrm{A}_{600}\right.\right.\right.$ $24 \mathrm{~h}$ with antimicrobial compound $-\mathrm{A}_{600} 0 \mathrm{~h}$ with antimicrobial compound $) /\left(\mathrm{A}_{600} 24 \mathrm{~h}\right.$ control $-\mathrm{A}_{600}$ 0h control)]] x 100 and expressed in \%.

Tartaric acid showed a MIC of $2000 \mathrm{mg} / \mathrm{L}$ for $S$. cerevisiae (CCT 2652) and $4000 \mathrm{mg} / \mathrm{L}$ for $S$. cerevisiae M26 (Table 1). For sodium gluconate, a MIC more than $2000 \mathrm{mg} / \mathrm{l}$ was found for all the strains tested. These values of MIC, therefore, were not recommended for bacterial control, because the industrial dosage of biocides and antibiotics used in Brazilian distilleries have been $10-20 \mathrm{mg} / \mathrm{L}$, and $3-4 \mathrm{mg} / \mathrm{L}$, respectively. Furthermore, these products inhibited the yeasts as well as the bacteria.

From the pure cationic surfactants (Table 1) available, only cetyl trimethyl ammonium chloride - CTAC (Fig. 1) inhibited L. fermentum with a MIC between 3.12-6.25 mg/L. However, these values were close for $S$. cerevisiae (MIC 6.25-12.5 $\mathrm{mg} / \mathrm{L}$ ). Autoclaved or microfiltered $\mathrm{Cba}$ or Cbe showed higher values (MIC $\geq 6.25 \mathrm{mg} / \mathrm{L}$ ) than CTAC for both $L$. fermentum and similar MIC for $S$. cerevisiae. These results showed that pure cationic surfactants (Cbe, Cba and CTAC) could not be not recommended for the control of bacterial contamination in the fermentation process of fuel ethanol by S. cerevisiae. However, Cba is currently used in cane milling steps of fuel ethanol production to bacterial control, mainly for the control of Leuconostoc mensenteroides and Lactobacillus sp at 10-20 mg/L. Ammonium quaternary (QA) compounds, dithiocarbamate and halogenated phenols have been used in Brazilian distilleries (Cereda et al. 1981). Sanitization with QA compounds has been performed and has saved as much as $60 \%$ of sugar loss from lactic acid bacteria contaminants in the sugar industry (Tilbury et al. 1977). N alkyl-di-methyl-benzyl ammonium chloride (Cba) showed a similar MIC $(8.0 \mathrm{mg} / \mathrm{L})$ for $S$. cerevisiae, $L$. fermentum and $L$. mesenteroides in fuel bioethanol distilleries, therefore, it would not be a practical additive for alcoholic fermentation process, since yeast cells could also be inhibited by this compound at the dosage necessary for bacterial growth inhibition (Oliva-Neto and Yokoya 1998).

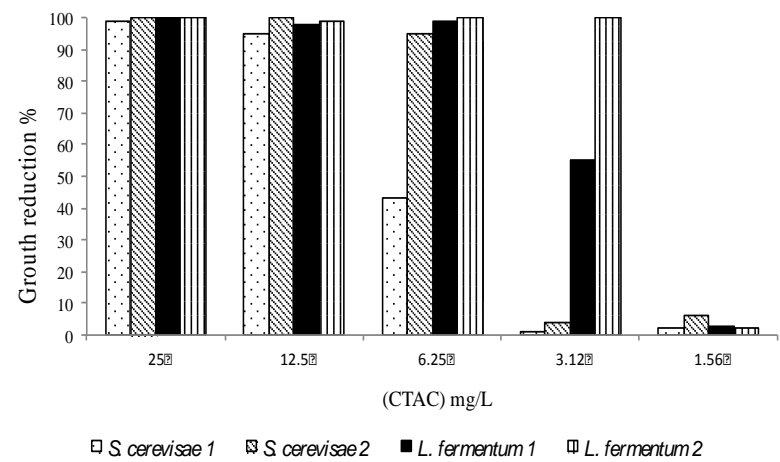

Figure 1 - Effect of cetyl trimethyl ammonium chloride (CTAC) on growth reduction (\%) of Saccharomyces cerevisiae CCT 2652 (1) and FCLA M26 (2), and Lactobacillus fermentum CCT 0559 (1) and CCT 1396 (2).

Pure TCC presented an MIC of $6.25 \mathrm{mg} / \mathrm{L}$ for the tested bacterium at $\mathrm{pH} 6.0$ and $3.12 \mathrm{mg} / \mathrm{L}$ at $\mathrm{pH}$ 4.0 (Table 1). The latter $\mathrm{pH}$ was similar to industrial conditions. This compound was effective against Gram positive bacteria. For example, an MIC against Staphylococcus aureus of $0.078 \mathrm{mg} / \mathrm{L}$ has been reported by Hamilton (1971) and TCC action against L. mesenteroides $(\mathrm{MIC}=0.5 \mathrm{mg} / \mathrm{L})$ and $L$. fermentum $(0.5-2.0$ $\mathrm{mg} / \mathrm{L}$ ) has been reported by Oliva-Neto and Yokoya (1988), which were similar to the levels reported in the present work. TCC did not inhibit $S$. cerevisiae growth in concentrations similar to $L$. fermentum $(\mathrm{MIC}=12.5 \mathrm{mg} / \mathrm{L})$. An MIC higher to $200 \mathrm{mg} / \mathrm{L}$ against $S$. cerevisiae has been reported by Oliva-Neto and Yokoya (1988).

The synergism between TCC and cationic surfactants $\mathrm{CBe}$ and $\mathrm{CBa}$ inhibited bacterial growth. A formulation with a mixture of these compounds was justified because TCC was not water soluble and pure ammonium quaternary compounds inhibited yeast growth. The combination of TCC and CBe $(1: 1 \mathrm{w} / \mathrm{w})$ showed a decrease in the MIC of TCC against $L$. fermentum compared to pure TCC (Table 2). This microfiltered formulation was more effective (MIC $3.12 \mathrm{mg} / \mathrm{l}$ ) than the autoclaved (MIC $=6.12$ $\mathrm{g} / \mathrm{L})$. Nevertheless, the TCC/CBe formulation did not inhibit $S$. cerevisiae (MIC $>12.5 \mathrm{mg} / \mathrm{l}$ ) in the tested concentrations, which was an important condition for the application of this product on an industrial scale for fuel ethanol production. 
Table 1 - Minimum Inhibitory Concentration (MIC) for several chemicals against Lactobacillus fermentum and Saccharomyces cerevisiae, at $32^{\circ} \mathrm{C}$ for $24 \mathrm{~h}$.

\begin{tabular}{|c|c|c|c|c|}
\hline \multirow[b]{2}{*}{ Chemicals } & \multicolumn{2}{|c|}{ MIC (mg/L) } & \multicolumn{2}{|c|}{ Cultures } \\
\hline & $\begin{array}{l}\text { S. cerevisiae } 1 \\
\text { CCT } 2652\end{array}$ & $\begin{array}{l}\text { S.cerevisiae } 2 \\
\text { FCLA M26 }\end{array}$ & $\begin{array}{l}\text { L. fermentum } 1 \\
\text { CCT } 0559\end{array}$ & $\begin{array}{l}\text { L. fermentum } 2 \\
\text { CCT } 1396\end{array}$ \\
\hline Tartaric acid & 2000 & 4000 & $\geq 4000$ & $\geq 4000$ \\
\hline Sodium gluconate & $\geq 2000$ & $\geq 2000$ & $\geq 2000$ & $\geq 2000$ \\
\hline Acetone & $>12.5$ & $>12.5$ & $>12.5$ & $>12.5$ \\
\hline $\mathrm{CBe}^{1}$ & $>12.5$ & $>12.5$ & $>12.5$ & $>12.5$ \\
\hline $\mathrm{CBa}^{2}$ & $>12.5$ & 12.5 & 12.5 & 12.5 \\
\hline $\mathrm{CBa}^{3}$ & 12.5 & 6.25 & $>12.5$ & 12.5 \\
\hline $\mathrm{CTA}^{1}$ & 12.5 & 6.25 & 6.25 & 3.12 \\
\hline $\mathrm{TCC}^{1}$ & $>12.5$ & $>12.5$ & 12.5 & 12.5 \\
\hline $\mathrm{TCC}^{2}$ & $>12.5$ & $>12.5$ & 6.25 & 6.25 \\
\hline $\mathrm{TCC}^{3}$ & $>12.5$ & $>12.5$ & 3.12 & 3.12 \\
\hline
\end{tabular}

Symbols: TCC - 3,4,4' trichlorocarbanilide, CBe - benzethonium chloride, CBa - benzalkonium chloride, CTA - Cetyl trimethyl ammonium chloride. ${ }^{1}$ - autoclaved product, culture of $\mathrm{pH} 6.0$ for L. fermentum, ${ }^{2}$ - microfiltered product, culture of pH 6.0 for L.fermentum ${ }^{3}$ - microfiltered product, culture of $\mathrm{pH} 4.0$ for L. fermentum.

Table 2 - Minimum Inhibitory Concentration (MIC) for different formulations of TCC and ammonium quaternary compounds and $\mathrm{Hj}$ Kamoran ${ }^{\circledR}$ against Lactobacillus fermentum and Saccharomyces cerevisiae, at $32^{\circ} \mathrm{C}$ for $24 \mathrm{~h}$.

\begin{tabular}{|c|c|c|c|c|}
\hline \multirow[b]{2}{*}{ Chemicals } & \multicolumn{2}{|c|}{ MIC (mg/L) } & \multicolumn{2}{|c|}{ Cultures } \\
\hline & $\begin{array}{l}\text { S. cerevisiae } 1 \\
\text { CCT } 2652\end{array}$ & $\begin{array}{l}\text { S.cerevisiae } 2 \\
\text { FCLA M26 }\end{array}$ & $\begin{array}{c}\text { L. fermentum } 1 \\
\text { CCT } 0559\end{array}$ & $\begin{array}{c}\text { L. fermentum } 2 \\
\text { CCT } 1396\end{array}$ \\
\hline $\mathrm{TCC}+\mathrm{CBe}^{1}$ & $>12.5$ & 12.5 & 6.25 & 6.25 \\
\hline $\mathrm{TCC}+\mathrm{CBe}^{2}$ & $>12.5$ & $>12.5$ & 3.12 & 3.12 \\
\hline $\mathrm{TCC}+\mathrm{CBe}^{3}$ & $>12.5$ & $>12.5$ & 6.25 & 6.25 \\
\hline $\mathrm{TCC}+\mathrm{CBa} 5: 1^{2}$ & $>12.5$ & $>12.5$ & 6.25 & 6.25 \\
\hline $\mathrm{TCC}+\mathrm{CBa} 2.5: 1^{2}$ & $>12.5$ & 12.5 & 3.12 & 3.12 \\
\hline $\mathrm{TCC}+\mathrm{CBa} 1: 1^{2}$ & $>12.5$ & 12.5 & 1.56 & 1.56 \\
\hline $\mathrm{TCC}+\mathrm{CBa} 2.5: 1^{1}$ & $>12.5$ & $>12.5$ & 12.5 & 12.5 \\
\hline HJ Kamoran ${ }^{1}$ & $>0.312$ & $>0.312$ & 0.156 & 0.078 \\
\hline HJ Kamoran ${ }^{2}$ & $>0.625$ & $>0.625$ & 0.312 & 0.156 \\
\hline
\end{tabular}

Symbols: TCC - 3,4,4' trichlorocarbanilide, CBe - benzethonium chloride, CBa - benzalkonium chloride, CTA - Cetyl trimethyl ammonium chloride. Hj Kamoran - commercial product (antibiotic Monensin). ${ }^{1}$ - autoclaved product, culture of $\mathrm{pH}$ 6.0 for L. fermentum, ${ }^{2}$ - microfiltered product, culture of $\mathrm{pH} 6.0$ for $L$. fermentum, ${ }^{3}$ - microfiltered product, culture of $\mathrm{pH} 4.0$ for L. fermentum.

The synergistic effect between TCC and CBa was also observed. The proportional increase of TCC in relation to $\mathrm{CBe}$ caused an increase in the MIC against $L$. fermentum (Table 2). The MIC observed with $\mathrm{TCC} / \mathrm{CBa}$ at $5: 1(\mathrm{w} / \mathrm{w})$ was $6.25 \mathrm{mg} / \mathrm{L}$, but the best MIC was $1: 1(\mathrm{w} / \mathrm{w})(1.56 \mathrm{mg} / \mathrm{L})$ for L.fermentum and only $12.5 \mathrm{mg} / \mathrm{L}$ for $S$. cerevisae (Fig. 2). This result was probably observed because the surfactant led a better dilution of TCC in the broth, which was associated with the inhibitory action of these products. According these results, if $\mathrm{CBa}$ was used in sugar cane milling at 1:1 ratio with TCC, it resulted 8 times reduction of $\mathrm{CBa}$ since this value was the quotient of pure CBa and CBa:TCC (1:1) MIC. The MIC of autoclaved TCC/CBa $(2.5: 1, \mathrm{w} / \mathrm{w})$ decreased four times in relation to this microfiltered formulation, probably because this formulation was not heatresistant. However, TCC/CBa formulation showed a higher MIC $(\geq 12.5 \mathrm{mg} / \mathrm{L})$ against $S$. cerevisiae than $L$. fermentum. In this work, a ratio lower to 1:1 TCC:CBa was not available, but it was possible that the MIC against $L$. fermentum could be even lower. The improvement in antibacterial action of TCC when combined with surfactants follows the same pattern of TCC/Cbe. The surfactant probably improved the TCC solubility in bacterial cells, since the MICs of the chemicals $\mathrm{CBa}$, Cbe, and TCC against L. fermentum were higher than those of the combined products. 


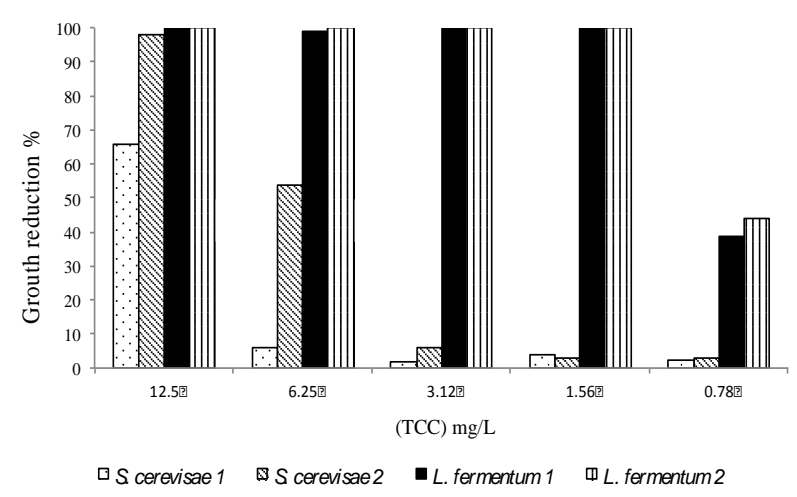

Figure 2 - Effect of 3,4,4' trichlorocarbanilide (TCC) and benzalkonium chloride (CBa) (1: 1 w/w) on growth reduction (\%) of Saccharomyces cerevisiae CCT 2652 (1) and FCLA M26 (2), and Lactobacillus fermentum CCT 0559 (1) and CCT 1396 (2).

The MIC of autoclaved $\mathrm{Hj}$ Kamoran ${ }^{\circledR}$ against $L$. fermentum was the lowest found in this study (0.078-0.156 mg/L) and higher to the microfiltered formulation $(0.156-0.312 \mathrm{mg} / \mathrm{L})$, probably due to its heat-resistance and loss in the microfiltration process (Fig. 3). $\mathrm{Hj}$ Kamoran $^{\circledR} \quad$ (antibiotic monensin) is currently used in bioethanol distilleries in Brazil and is the most important product for the control of bacterial infections in industrial alcoholic fermentation. The usual dosage in distilleries was formerly $1.0-3.0 \mathrm{mg} / \mathrm{L}$ (Oliveira et al. 1996) but has now been increased to $3.0-4.0 \mathrm{mg} / \mathrm{l}$. This was probably due to an increase in bacterial resistance to the antibiotic.

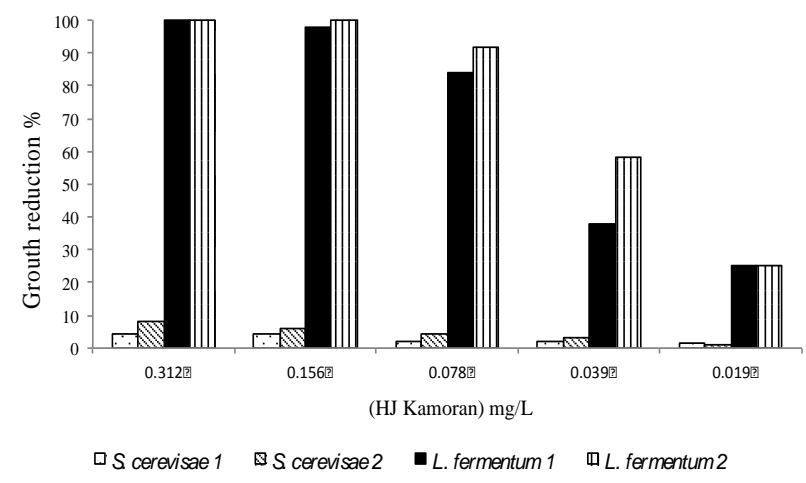

Figure 3 - Effect of HJ Kamoran ${ }^{\circledR}$ (monensin) on growth reduction (\%) of Saccharomyces cerevisiae CCT 2652 (1) and FCLA M26 (2), and Lactobacillus fermentum CCT 0559 (1) and CCT 1396 (2).
Autoclaved $\mathrm{Hj}$ Kamoran ${ }^{\circledR}$ presented an average MIC against $L$. fermentum (0.117 mg/L) 13.3 times lower than formulated TCC/CBa (1:1) MIC. Nevertheless, despite the efficiency of $\mathrm{Hj}$ Kamoran $^{\circledR}$, the formulation TCC/Cba could be improved. It would be worth considering that these types of biocides were usually cheaper than antibiotics. Furthermore, the biocide mechanism of bacterial growth inhibition is generally less specific than that of antibiotics, and this factor may make it more difficult for bacteria to become the resistant to TCC/CBa.

Table 3 shows the MICs obtained for chemotherapeutic agents. Nalidixic acid, pipemidic acid, phenazopyridine, sulphadiazine silver, sulphasalazine, gentamicin sulfate, sulfamethoxazol/ trimethoprim, sulfacetamide sodium and polymyxin B sulphate showed MICs higher than $40 \mathrm{mg} / \mathrm{L}$ against L. fermentum. Since the usual concentrations of antibiotics used in fuel ethanol fermentation were lower than $4.0 \mathrm{mg} / \mathrm{L}$, these compounds could not be recommended to control lactic acid bacterial contaminants of alcoholic fermentation. As for gentamicin, some authors have reported a resistance of $57.7 \%$ in Lactobacillus spp. from the fermented products (Olukoya et al. 1993). Moreover, it has been shown that the MIC of gentamicin for $L$. plantarum was almost $128 \mathrm{mg} / \mathrm{L}$ and indeed this antibiotic did not perform well against other species of the Lactobacillus genus (Rojo-Bezares et al. 2006). The MIC of polymyxin B sulphate for L. fermentum has been reported as $64 \mathrm{mg} / \mathrm{l}$, which was higher than $1024 \mathrm{mg} / \mathrm{L}$ for other species of this genus (Florez et al. 2008). An MIC >1024 $\mathrm{mg} / \mathrm{L}$ for sulphamethoxazole against Lactobacillus spp. has also been reported. These results confirmed previous reports about the intrinsic resistance presented by the genus Lactobacillus. Sulfas are competitive inhibitors of enzymes that convert the substrate para-aminobenzoic acid (PABA), an essential nutrient used by many bacteria, for use in the synthesis of the coenzyme folic acid (Tortora et al. 1998). Lactic acid bacteria, however, do not produce folic acid, and so sulfonamides such as sulfamethoxazol and sulfacetamide are inactive against Lactobacillus spp. (Katila et al. 2001).

Resistance to gentamicin is associated with membrane impermeability of the Lactobacillus spp. (Elkins and Mullis 2004). With respect to metronidazole, this antibiotic was not effective in inhibiting either bacterial or yeast growth, 
presenting an MIC > $200 \mathrm{mg} / \mathrm{l}$ for Lactobacillus spp. Furthermore, it has been reported that 128 $\mathrm{mg} / \mathrm{l}$ metronidazole may actually stimulate Lactobacillus growth (Choi et al. 2003). Nitrofurantoin was the only chemoterapeutic agent that provided an inhibitory effect against $L$. fermentum, $(\mathrm{MIC}=15 \mathrm{mg} / \mathrm{L})$, but it took higher concentrations than the antibiotics normally used in fuel ethanol fermentation. The effectiveness of nitrofurantoin against Lactobacillus spp. has been previously reported (MIC $8.0 \mathrm{mg} / \mathrm{l}$ ). More specifically, for six strains of $L$. acidophilus, its MIC was reported as $2.0 \mathrm{mg} / \mathrm{L}$ (Danielsen and Wind 2003).

Table 3 - Minimum Inhibitory Concentration (MIC) of several chemotherapeutic agents against Lactobacillus fermentum and Saccharomyces cerevisiae.

\begin{tabular}{lcccc}
\hline \multirow{2}{*}{ Antimicrobial Agents } & \multicolumn{3}{c}{$\begin{array}{c}\text { Minimum Inhibitory Concentration (mg/L) } \\
\text { Cultures }\end{array}$} \\
\cline { 2 - 5 } & $\begin{array}{c}\text { L.fermentum } \\
\text { CCT 1396 }\end{array}$ & $\begin{array}{c}\text { L.fermentum } \\
\text { CCT 0559 }\end{array}$ & $\begin{array}{c}\text { S. cerevisiae } \\
\text { CCT 4370 }\end{array}$ & $\begin{array}{c}\text { S. cerevisiae } \\
\text { FCLA M26 }\end{array}$ \\
\hline Gentamicin sulphate & $>40$ & $>40$ & $>40$ & $>40$ \\
Metronidazole & $>40$ & $>40$ & $>40$ & $>40$ \\
Nalidixic acid & $>40$ & $>40$ & $>40$ & $>40$ \\
Nitrofurantoin & 15 & 15 & $>40$ & $>40$ \\
Nitrofurantoin+SDS(1:1) & 15 & 15 & $>40$ & $>40$ \\
Nitrofurantoin+SDS(3:1) & 15 & 15 & $>40$ & $>40$ \\
Phenazopyridine hydrochloride & $>40$ & $>40$ & $>40$ & $>40$ \\
Pipemidic acid & $>40$ & $>40$ & $>40$ & $>40$ \\
Polymyxin B sulphate & $>40$ & $>40$ & $>40$ & $>40$ \\
Silver sulphadiazine & $>40$ & $>40$ & $>40$ & $>40$ \\
Sulfacetamide sodium & $>40$ & $>40$ & $>40$ & $>40$ \\
Sulphamethoxazole/trimethoprim & $>40$ & $>40$ & & $>40$ \\
Sulphasalazine & $>40$ & & & \\
\hline
\end{tabular}

\section{CONCLUSION}

There was a synergistic effect between 3,4,4' trichlorocarbanilide (TCC) and benzethonium chloride $(\mathrm{CBe})$ or benzalkonium chloride $(\mathrm{CBa})$, improving the inhibitory action against the growth of L. fermentum. These formulations also increased the selective action only on bacteria, not inhibiting the growth of $S$. cerevisiae. The best MIC $(1.56 \mathrm{mg} / \mathrm{L})$ of the combined chemicals against $L$. fermentum was obtained by the formulation TCC: CBa 1:1 (w/w). CBa could be tested in sugar cane milling in 1:1 ratio with TCC since a reduction of 8 times in the use of this product was possible. This formulation also should be tested in fermentation steps since it was more difficult for the bacteria to develop resistance to biocide. There was no inhibition of $S$. cerevisiae. Currently, there are only antibiotics as an option to bacterial control of fuel ethanol fermentation by $S$. cerevisiae. The present results demonstrated the importance of further studies about the TCC mixed with surfactants for the improvement of fuel bioethanol technology.

\section{ACKNOWLEDMENTS}

The authors thank the Fundação de Amparo à Pesquisa do Estado de São Paulo - FAPESP (Brazil) for financial support, Fundação Tropical André Tosello for the donations of the cultures.

\section{REFERENCES}

Cereda MP, Serra GE, Cagliari AM, Meneguim MA. Microbial method for evaluating antiseptics used in alcohol industry. Brasil Açucareiro. 1981; 97: 44-51.

Choi SY, Chang CE, Kim SC, So J. Antimicrobial susceptibility and strain prevalence of Korean vaginal Lactobacillus spp. Anaerobe. 2003; 9: 277-280.

Danielsen M, Wind A. Susceptibility of Lactobacillus spp. to antimicrobial agents. Int J Food Microbiol. 2003; 82: 1-11. 
Dorta C, Oliva-Neto P, Abreu-Neto MS, Nicolau-Junior N, Nagashima AI. Synergism among lactic acid, sulfite, $\mathrm{pH}$ and ethanol in alcoholic fermentation of Saccharomyces cerevisiae (PE-2 and M-26). World J Microbiol Biotechnol. 2006; 22: 177-182.

Elkins CA, Mullis LB. Bile mediated amiloglycoside sensitivity in Lactobacillus species likely results from increased membrane permeability attributable to cholic acid. Appl. Env. Microb. 2004; 70(12): 72007209.

Essia-Ngang JJ, Letourneau F, Villa P. Alcoholic fermentation of beet molasses effects of lactic acid on yeast fermentation parameters. Appl Microb Biotechnol. 1989; 31: 125-128.

Florez AB, Ammor MS, Mayo B. Antimicrobial susceptibility profiles of 32 strains of Lactobacillus, Bifidobacterium, Lactococcus and Streptococcus spp. Intern J Antimicrob Agents. 2008; 3: 484-504.

Gallo CR. Determinação da microbiota bacteriana de mosto e de dornas de fermentação alcoólica. Campinas, Ph.D. Thesis. Faculdade de Engenharia de Alimentos - UNICAMP. 1989; 338p.

Hamilton WA. Membrane active antibacterial compounds. In: Hugo, W.B (ed.). Inhibition and destruction of the Microbial Cell. Academic Press: New York, 1971; 230-235.

Jones RN, Barry AL, Gavan TL, Washington II JA. Susceptibility tests: Microdilution and Macrodilution broth procedures. In: Lennette EH, Balows A, Halousler WJJr., Shadom Y. (eds). Manual of Clinical Microbiology, American Society of Microbiology: Washington - DC, 1985; 972-977.

Katla AK, Kruse H, Johsen G, Herikstad H. Antimicrobial susceptibility of starter culture bacteria used in Norwegian dairy products. Int J Food Microb. 2001; 67: 147-152.

Ludwig KM, Oliva-Neto P, Angelis DF. Quantification of Saccharomyces cerevisiae flocculation of contaminants in alcoholic fermentation by bacteria. Cienc Tecnol Aliment. 2001; 21: 63-68.

Maiorella B, Blanch HWC, Wilke CR. By Product inhibition effects on ethanolic fermentation by Saccharomyces cerevisiae. Biotech Bioeng. 1983; 25: 103-121.

Oliva-Neto, P. Influence of contamination by lactic acid bacteria in alcoholic fermentation by fed batch process. Master Thesis, Faculdade de Engenharia de Alimentos - UNICAMP. Campinas, 1990; 200p.

Oliva-Neto P, Yokoya F. Evaluation of bacterial contamination in a fed-batch alcoholic fermentation process. World J Microbio Biotechnol. 1994; 10: 697 699.
Oliva-Neto P, Yokoya F. Influence of yeast extract on the stability of contaminated alcoholic fermentation by Lactobacillus fermentum. Ciênc Tecnol Aliment. 1996; 16: 170-174.

Oliva-Neto P, Yokoya F. Effect of 3,4,4'trichlorocarbanilide on growth of lactic acid bacteria contaminants in alcoholic fermentation. Bioresource Technol. 1998; 63: 17-21.

Oliva-Neto P, Yokoya F. Susceptibility of Saccharomyces cerevisiae and lactic acid bacteria from the alcohol industry to several antimicrobial compounds. Braz J Microbiol. 2001; 32: 10-14.

Oliva-Neto P, Ferreira MA, Yokoya F. Screening for yeasts with antibacterial properties from an ethanol distillery. Bioresource Technol. 2004; 92: 1-6.

Oliveira AJ, Gallo CR, Alcarde VE, Godoy A, Amorim HV. Methods for microbiological control in the production of sugar and alcohol. Piracicaba: FERMENTEC - ESALQ, Piracicaba, Brazil. 1996; 89p.

Olukoya, DK, Ebigwei, SI, Adebano, OO, Osiyemi, FO. Plasmid profiles and antibiotic susceptibility patterns of Lactobacillus isolated from fermented foods in Nigeria. Food Microb. 1993; 10:279-285.

Rojo-Bezares B, Saenz Y, Poeta P, Zararaga M, RuitzLarrea F, Torres C. Assessment of antibiotic susceptibility within lactic acid bacteria strains isolated from wine. Int J Food Microbiol. 2006; 111: 234-240.

Silva ED, Silva SA, Nogueira LC, Oliva-Neto P. Susceptibility of Saccharomyces cerevisiae and lactic acid bacteria on aldehydes and surface active agents on medium with sugar cane juice. II Simpósio de Ciência de Alimentos, Campinas, SP - Brazil. 1997.

Tilbury RH, Hollingsworth BS, Graham SD, Pottage P. Mill sanitization - a fresh approach to biocide evaluation. Proceeding of I.S.S.C.T. XVI Congress, 1977; 2749-2768.

Tortora GJ, Funk BR, Case CL. Microbial Metabolism Energy production. In: Microbiology - An Introduction. Addison Wesley Longman Inc. California - USA. 1998; p.118.

Yokoya F, Oliva-Neto P. Characteristics of yeast flocculation by Lactobacillus fermentum. Rev Microbiol. 1991; 22: 21-27.

Received: August 06, 2012; Accepted: December 23, 2013. 